\title{
Social Responsibility Cost and Its Influence on the Profitability of Nigerian Banks
}

\author{
Peter Kekung Bessong, B.Sc., M.Sc., Ph.D \\ Department of Accounting, Faculty of Management Sciences, University of Calabar, P.M.B.1115., Calabar, Nigeria \\ Tel: 234-80-3707-9607 \\ Arzizeh Tiesieh Tapang, B.Sc., M.Sc. \\ Faculty of Management Sciences, University of Calabar, P.M.B.1115., Calabar, Nigeria \\ Tel: 234-80-3273-7920,234-80-9551-4973E-mail: arzizeh01@yahoo.com
}

\author{
Received: June 7, 2012 \\ Accepted: July 25, 2012 \\ Online Published: October 11, 2012 \\ doi:10.5430/ijfr.v3n4p33 \\ URL: http://dx.doi.org/10.5430/ijfr.v3n4p33
}

\begin{abstract}
This study aims at determining the influence of social responsibility cost on the profitability of Nigerian banks. In order to control environmental cost and the impact of the potential hazards presented by the operations of firms in the banking industry, such firms usually strive to act socially responsible ways. The study made used of an exploratory research design and data were collected from five Nigerian banks through secondary sources and analyzed using the Ordinary Least Square (OLS) method. The study revealed that there is a negative influence between social cost and pollution cost on profitability. Conclusively, social responsibility cost is as vital as all other liabilities of the banks, and it requires proper management. It is recommended that the Financial Reporting Council (FRC) of Nigeria should collaborate with other professional bodies, the academia and other stakeholders to produce a standard on social responsibility accounting and should ensure there is compliance and transparency in the process.
\end{abstract}

Keywords: Social cost, Pollution cost, Social responsibility, Social responsibility cost, Social reporting and stakeholders

\section{Introduction}

The role of business in society is changing dramatically. Business exists within an environment, that is to say that business does not exit in isolation, but functions in an environment. The society affects business and is in turn affected by the business. The business in its operation in the environment affects the latter positively and hazardously.

The society on the other hand affects the performance of business by making demand for compensation, provision of social amenities, and employment of indigenes to top management position and sponsorship of indigenes in schools. And so, for the business to operate harmoniously and positively affects the society, it has to be financially involved in the provision of social amenities such as electricity, borehole water, hospital, etc. some of its vast economic power has to be devoted to social programmes, rehabilitation of the environmental effects. Business has also to be financially involved in giving scholarship to the society members in tertiary institutions and training some others in skilled vocation.

In view of this, the inter relationship between business and its society has become increasingly important. The society and organizations are quite aware and conscious of this interdependence. As a result, organizations are no longer viewed to be totally private endeavours that are free to pursue their ends as long as they break no law (s). Instead, their actions are seen as having public consequences that go beyond serving customers and paying returns to owners. The outcome of this notion is a rising public clamour for social responsibility or social responsiveness on the part of business.

In the broadest sense, the net effect of social responsibility is to improve the quality of life, which is determined by the society. It also harmonizes business actions aimed at achieving the performance of business (such as profit and growth) with the society's want (social benefit). 
The idea of society responsibility recognises that each person is attached to an extended social system on which he or she is partly dependent. Consequently, certain obligations or social responsibilities arise from this attachment. The concepts of social responsibility are broad and general. They do not explain very precisely what social responsibilities are for all business, or what those of single business are at a particular point in time. Unfortunately, there is no standard for this, and has been a subject of substantial disagreement.

Advocates of social responsibility argue that organisations have a wide range of responsibilities that extend beyond production of goods and services at a profit. As members of society business should actively and responsively participate in the community and in the larger environment. Others contend that socially responsible actions have long-term advantages for organization. Organisations can improve their images and avoid unnecessary and costly regulation if they are perceived as socially responsible. Also, society's problem can offer business opportunities and profits can be made from systematic and vigorous efforts to solve these problems. In order words, it pays to be good.

The establishment of companies in any society is a welcome development. This is because the environment is open to other economic activities indirectly and job creation directly as a result of the presents of the companies. Various forms of companies are scattered here and there in any environment that has resources both natural and other attractions. The companies include extractive, manufacturing and services. All these have their own negative impact depending on the nature of business undertaken by the company.

The basic causes of our environmental problems are complex and dynamic. They include the tendency to emphasize quantitative costs to the exclusion of intangible and social costs of environmental activities; a failure to perceive the environment in its totality; and a lack of understanding and recognition of the fundamental interdependence of all its parts, including man himself.

The banking industry occupies a key position in the economic life of a nation. This industry supplies a vast range of products which are utilized across a wide spectrum of human activities. Some of these products, are however potentially hazardous while others corrosive.

In order to control environmental cost and the impact of the potential hazards presented by the operations of firms in the banking industry, such firms usually strive to act socially responsible ways. Social responsibility typically involves costs that firms bear which have some effect on their financial performance. Economic theory suggests that social responsibility cost is negatively associated with profitability. As such, attempting to act in a way that is socially responsible impacts negatively atleast in the short run on the performance of the bank. The specific cost that is often identified in this regard includes those related to the provision of facilities that support the well-being of the firm's communities or publics (social cost) and pollution cost. The problem of this study is to establish the extent to which social responsibility cost influence the performance of firms in the banking industry of Nigeria.

In an attempt to answer the above stated problem these null research hypotheses are formulated:

1) $\mathrm{H}_{0}$ : Social responsibility cost does not significantly influence profitability of Nigerian banks.

2) $\mathrm{H}_{\mathbf{0}}$ : Pollution cost does not significantly influence profitability of Nigerian banks.

\section{Literature Review and Theoretical Framework}

\subsection{Literature Review}

Owing to the varied and multi-faceted nature of the subject of social responsibility, studies over the world especially concerning sustainability can be classified into several typologies, which among others includes analytical and descriptive studies; which analyze the different phenomenon that enhance sustainability in difference circumstances. This covers case studies whose focus is on the functional attribute of the economic environment and their relationship with both individuals and organizations in the environment; institutional studies which are concerned with their contribution to cost-efficiency and general text studies which analyze generally all aspect of environmental issues.

In essence, most studies are within the context of general text which when looked at, is not particularly the focus of this study except that an understanding of the general frame of organization - environmental exchange would enhance our appreciation of their effect on the profitability of organizations. This research limits itself to the contextual issues on the subject while drawing lessons of experience from relevant studies for purpose of illustration and comparability. These studies are spread over the world in different circumstances, experiences etc. which makes the study of social responsibility activities quite complicated even when such activities are examined within a set paradigms or conceptualization.

The United Nations Organization (UNO) has done tremendous work on the issue of social responsibility activities in 
the different aspect concerning it sustainability, management and control etc. and the overall impact in the world economy. Prominently the data presented by the United Nations relating to promoting the integrity of the natural environment for the present and future generation.

Substantial effort and resources have been deplored to ensure that our natural environment is not treated as a free good. These efforts and resources are supplemented generally by scholarly works by a number of environmentalists.

Arntzen (1997) who reviewed the report of the World Conference on Environmental Development (WCED, 1987 Brundtland Report) had this to say: "The concept articulated in Brundtland Report States, that if humans continue to produce or manufacture, exploit the natural resources and reproduce in numbers at the present rate, then they will narrow sharply chances of prosperity, or even of safe and secure livelihood for the next and subsequent generations". In his opinion this basic assumption of sustainability implies that natural resources should be treated, as production factors, which needs to be used and maintained, first like any other man-made capital. Gilpin (1995) referred to this sustainability as the use of incremental increases without reducing the total physical stock of the environment. Hence, all development and exploration or exploitation activities must be carried out with due concern for the environment (Salamis, 2000).

In the view shared by Rilwani (2001), he said, "World over, widespread concern has arisen about the nature of development. In the context of social and environmental as well as economic consideration development projects usually evaluated under the framework of cost benefit analysis" (p.142). If the moral obligation of such programme and project to future generations are considered the analytical framework becomes increasingly complex. A fundamental response to these concerns and questions has been the concept of environmental management. This means the entire process of planning, managing and conserving the environment and natural resources (Eagles, 1984). In his summary on these issues, Rilwani (2001) said environmental management is a set of activities and procedure, properly seen as the integral elements of the developmental process, aimed at ensuring that developmental activities affecting the environment:

(i) provides net benefit to society

(ii) are sustainable

(iii) allows for continuation of valuable non-consumption uses of ecosystems.

Ozumba (1999) observed that the reverse had rather been the case over the years. He said that the environment is thus pollutedly improvised. Only a clean and safe environment can support life of the present generation and that of future generations. And that man and animal could be extinct if our environment is not preserved. At the fundamental level environment provides a biological, chemical and physical system that enables human life to exist (Smith, 2003). Due to increase in industrial expansion, activities and human population in the modern age, environmental resources and capabilities have increasingly been stressed beyond their limit.

Social responsibility accounting is an important tool for understanding the role played by the natural environment in the economy. Social responsibility accounting provide data which highlight both the contribution of natural resources to economic well-being and the cost imposed by pollution or resources degradation(IUCN,1980). A company's attitude to the environment is likely to be seen as a benchmark of its commitment to innovation and good management (Ozumba, 1999). Companies setting the pace on social issues will be seen as the leaders of a corporate sector (Bailey, 1991). Social responsibility accounting specifically refers to the research or practice of accounting for an organizations impact on the natural environment (Gray, 2001).

According to (Growther, 2000), social accounting should provide information to all of the organization's stakeholders. He said that a stakeholder of an organization is anyone who can influence or is influenced by the organization.

Smith (2003) provided a useful analysis of the concept of social reporting. According to him, in the past, social issues were often ignored by both corporations and individuals. Hazardous waste and other such items were considered a necessary cost of a growing economy. He said that times have changed, as people now realized the effect of waste products that potentially could damage .the environment. Most people now recognize that preserving clean air, water and land is more important than lower-cost products for consumers or higher profit for business.

The point to note here is that maintaining clean production does not undermine the profit objectives of a firm. That is why Eyre (1982) said whatever the objectives laid down for a firm, however, there is no doubt that the objective of profit must be recognized as being of prime importance because only from profit can come the financial resources to support more socially inclined objective. Profitability therefore becomes a major determinant for any decision on the 
type of economic venture or area an organization can concentrate its activities (Buskirk, 1976). He goes on to say that the profit system is closely parallel to the concept of free enterprise for profit is the driving force behind the free enterprise. Profit is the fuel that propels enterprise etc. This in other words means profit is the motivating goal to make organization perform certain functions. The argument is that the advocacy of the goal of profitability of the interplay of the environment-organizational exchange can only be effective if in the final analysis, the positive effects of the comparative advantage between them (environment and the organization) are spread even; but as at now the experience is that the obligation has not been reciprocated by the organization. This is disadvantageous to intergenerational equity (sustainability). The environment has to be treated as an integral part of the economic process and not treated as free goods (Awasthi, 2009).

Aboribo (2001) asked "if the essence of business is to maximize profit and nothing more, what then is the social responsibility of the business world?"(p.125). He further stated that Joseph McGuire, in Business and society provided a persuasive focus when he asserted. "The idea of social responsibilities supposes that the corporation has not only economic and legal obligation but certain responsibilities to society which extend beyond these obligations". Thus it is clear from McGuire that despite the essence of business, it has certain responsibilities to society, which extend beyond the parameters set by law. Our inference from McGuire definition as (Yomere, 2000) pointed out is that "It is wrong to say that the sole objective of business is the creation, accumulation and distribution of wealth for the benefit of society itself. It is also equally wrong to say that business should forget all about the profit motive and the invaluable profit measures and simply settle down to do social good. Somewhere between these extreme positions lies the answer". The answer in this case is a corporate activity that promotes a more realistic view of social responsibility; that is activities that are profitable while at the same time socially responsible.

\subsection{Theoretical Framework}

Social responsibility includes a group of behavioural, social and ethical indicators and requirements. It has to do with serving the community and achieving public benefits, maintaining a balance between the basic organizational objectives and the sub-objectives related to the public interest, including health and social insurance, charitable donations and support of cultural and social activities. (Twaijn, 1988; Al-Hamadeen, 2002).

Gray, Javad, and Porter, (2001) defined environmental reporting as the process of providing information designed to discharge environmental accountability. Typically this act would be undertaken by the accountable organization and this might include information in the annual report, special publication or reports or even socially oriented advertising.

Many theories have been developed in the social reporting literature in trying to answer the question of why firms disclose social information, even though such disclosures are not enshrined in legislation equivalent to acts (Gray, Javad \& Porter, 2001). The following are some of the theories:

\subsubsection{The Stakeholder's Theory}

According to Eyre (1982: 180), "the rather simplistic view of management objectives put forward by economic theories has been challenged by sociologists and psychologists. The behavioural scientists contend that profit maximization alone is not, and cannot be the sole management objective". He went on to say that there is a believe that the employed manager hoped to satisfy his own personal benefit vis-à-vis the benefit of the organization. This implied that those saddled with the responsibility of formulating business objective (top management), should take into consideration the personal interest of the employed manager. There should be a deliberate management policy to satisfy the benefit of the employees. This will undoubtedly motivate the employees to achieve the firm's objective.

Drawing from the above inference, it is pertinent to argue that today's concern should not only be on the employees, but on the entire stakeholders of the organization. To achieve this aim every organization should be able to know who its stakeholders are. This often includes, but not limited to suppliers of inputs, employees and trade union, members of local communities, society at large, and government. Different stakeholders have different rights of information. This right can be stipulated by law, but also by non-legal codes, corporate values, mission statements, and moral rights, the rights of information are thus determined by society, the organization and its stakeholders. Simply put, a stakeholder analysis needs to be carried out to identify the relevant parties that have a stake in the organization. They could be individuals, groups, or organization. In view of the growing concern about the impact of organizations on our environment as well as the importance of the environment to the different stakeholders including the organization, there is a great need for management objective to be given wider scope. Management overall attainment of objective should no longer be viewed in terms of how much it has satisfied the need of the internal members and perhaps the government; the local community must be taken into consideration. 
To Buttress this point, behavioral scientists advance the stakeholders Theory. This theory states that "there are a number of interested parties to be considered in the formulation of objectives, and these extended widely to include not only shareholders and managers, but also other groups, such as workers, consumers, suppliers and local community" (Eyre, 1982: 185). Eyre in his submission concluded that this extended concern means that management objectives must be set to include the interest of all who are likely to be touched by the business activities of the firm. The emphasis is that interests of the stakeholders must be taken into account. In other words, if this policy is ignored or not given the attention it deserves, even the major objective of the organization being profit maximization will be adversely affected (Friedman, 1980).

In order to guard against this problem, it is expedient to identify the stakeholders of the organization and analyse their stake in the organization. (Cohen, 2001) advised that once all the possible stakeholders are identified, one should try to determine the following:

(a) What are their stakes in the organization?

(b) What are their needs/desire in relation to the organization and operation?

(c) What are their resources in relation to the attainment of organizational goal?

(d) Exactly how will they be affected by the organization?

(e) Is their co-operation/goodwill necessary, desirable, or important?

It is also necessary for the organization to analyze its role as well as relationship with the stakeholders, both individually and collectively. This will facilitate the setting out of healthy boundaries that will enhance effective and efficient operation (Cohen, 2001). A successful implementation of this preliminary plan will help management set objectives that will fulfill their own interest as well as produce profit that will satisfy the owners. The profit that will satisfy the owners here may not be the maximum profit, but a sustainable profit. This means a profit that satisfies the long term expectation of the organisation. Every plan for the attainment of the long-term goal of the organisation should and must incorporate the resources needed to achieve the set goal. These include the corporate environment. A growing body of evidence suggests that, in many situations, improved environmental and social performance provides financial benefit (Repetto, 1989).

\subsubsection{Normative Accountability Theory}

This theory states that the law becomes the social contract between the firm and society, and thus "forms the basis upon which accountability is built and upon which corporate social reporting can be justified and structured" (Gray, 1988, p47).

The accountability approach for social reporting has been criticized by Tinker, Neimark and Lehman (1991) on the ground that it does not take into consideration the distribution of power. In addition, because both law and quasi law are changeable they do not give an absolute ground for identifying the nature of responsibility.

\subsubsection{Agency Theory}

According to this theory, social disclosure as part of the overall disclosure by the firm is seen as a means by which managers and firms reduce agency cost. The approach has been widely criticized. Milne (2002) argues that SR literature based on positive accounting theory has to date failed to offer any substantive evidence whatsoever to support the view that firms' management use social disclosure in pursuit of their own wealth interests. Gray, Neimark and Lehman (1995) dismissed agency theory of social reporting by arguing that the "central assumption that all actions are motivated by a morally degenerate form of short term self interest seems not only empirically implausible but also highly offensive" (p25).

\subsubsection{Legitimacy Theory}

This theory states that business operates in society via a social contract where it agrees to perform various socially desirable actions in return for approval of its objectives and other rewards, which ultimately guarantees its survival (Guthrie \& Parker, 1989). It therefore needs to disclose enough social information to assess whether it is a good corporate citizen.

In legitimizing its actions via disclosure, the firm attempts ultimately to justify its continued existence. Firms may face situations that lead them to undertake legitimization activities, including SR. This approach to SR shares with stakeholders' approach the view that management controls information and decides how to deal with the shakeholders. However, more emphasis is placed on this approach on firms' purposes regarding SR. Campbell (2002) described the legitimacy theory of social reporting as empirically testable. On the contrary, Wilmshurst and Frost 
(2000) suggest that prior research has not provided consistent support for the legitimacy theory.

\subsection{The Concept of Accounting for Social Responsibility}

The concept of social accounting has become more important as a result of industrial growth which has brought about prosperity as well as problems to society. For an organization to function effectively, it needs to be accountable to the public at large. Social accounting is the branch of accounting which measures, analyzes and records the society and the enterprise itself both in quantitative and qualitative terms.

The call for developing types of social responsibility accounting came at the annual meeting of the American Accountants Association (AAA) in 1969, which urged accountants to evaluate development of the concepts of income on a social basis. In response to this call, the AAA and the American Association of Certified Accountants (AACA) formed economic social accountancy committees to deal with the issues.

\subsubsection{Social Responsibility}

Social responsibility can be defined as a group of activities concerned with the measurement of social performance of organizations and their role in maintaining the environment and providing different services to their local communities, directly or indirectly and reporting such results so that the community is able to evaluate the social performance of that organization (Twaijn, 1988; Al-Hamadeen, 2002). Through these activities the organization communicates relevant information to the targeted groups. Since the job of organization is not limited only to the maximization of profits and economic returns but, rather includes all environmental aspects and community service.

Therefore, all business organizations should perform the four types of social responsibility discussed below:

a) Humanitarian or voluntary responsibility

The benefits and privileges that society wishes to directly obtain from the organization, such as the support provided for projects aimed at improving the quality of life in the local community.

b) Ethical responsibility

Contributions or activities expected to be performed by the organization for society without being directed by legal stipulations.

c) Legal responsibility

Legislation designed to protect society which organizations should comply with.

d) Economic Responsibility

The duties of the establishment to generate products and services needed by society and offer them at prices that meet the acceptance of the community and serve the interest of investors. At the same time they collectively achieve continuity of the organization. Social responsibility includes in its broader sense, commitment to achieving a balance between the interests and needs of each stakeholders, including the organization, each of its workers, the environment and the society where it operates (Al-Hayali, 1998).

The activities of social responsibility can be classified into two major domains:

(a) At the commitment level: performance of specific activities stipulated in laws and regulations, but serving community purpose.

(b) In terms of quality of activities: Environmental protection activities, such as nature reserves, cleaning, and pollution prevention; activities related to workers represented in a group of benefits, privileges, and services, which have positive impacts on their welfare and that of their families, activities of interaction with the surrounding environment, including all activities that positively influence the society such as consumer protection activities.

\subsection{Areas of Social Accounting}

Four areas of social performance were identified: The interaction of organizations with the community; contribution to the development of human resources; contribution to the development of natural resources and environment and up grading the quality of products (Gray, 2002; Jebreel, 1999).

(i) Regarding community: This includes the group of activities aiming at achieving public benefits, such as employment of people with disabilities, training university students, and establishment of a kindergarten for children in the area, contributions to health care programmes development and welfare of the society (Gamble \& Jackson, 1996). 
(ii) Regarding workers: This includes the effect of the organization's activities on its workers as human resources. The organization here contributes to the improvement of the workers' conditions in general, such as the provision of free medical care and the means of occupational safety, which both represent and internal aspect of social accounting.

(iii) Regarding the environment: This includes social activities aimed at reducing the negative impact of the organization's operation on the environment. These activities are designed to preserve and protect the surrounding environment and natural resources. This is one of the most important aspects of social accounting due to the damage caused to the environment by water, air, soil, and noise pollution (Shacer, 1988).

(iv) Regarding consumer protection: This includes the activities aiming at achieving customer satisfaction and safeguarding their interests. Examples are product safety, and the provision of adequate information about a product in terms of methods and limits of usage, the associated risks and the validity period.

\subsection{Objectives of Social Accounting}

Social responsibility accounting seeks to determine and measure the net social contribution of the organization on a periodic basis. This not only includes the elements of internal cost and specific benefits of the organization, but also includes the social cost and external social benefits that influence segments of the community.

Secondly, it seeks to evaluate the social performance by identifying whether the organization's ambition to ensure that individuals connected with the firm, as stakeholders, have a reasonable percentage of profits. The relationship between the corporate performance of organizations and social welfare lies at the core of social responsibility accounting. This requires an appropriate mechanism to measure social performance.

Thirdly, to disclose the activities that have social impact carried out by the organization. This objective underlines the need for appropriate data on the social performance of the organization and the extent to which it contributes to achieving social objectives.

Fourthly, to highlight the need to convey such data to internal and external beneficiaries in a way that positively influences decisions made regarding activities at the private and public levels. To achieve this objective, an integrated information system should be worked out to reflect the objectives, policies, programmes, performance, and contribution of organization to social welfare. The system should be able to provide management and other relevant parties with useful information for decision making (Abul, 1998; Gray, 2002; Ibrahim, 2003).

\subsection{Disclosure of Social Responsibility Accounting}

Social Responsibility Reporting (SRR) is supposed to be a rational assessment of and meaningful reporting on the measurement of the activities of a business enterprise which have social impact.

The SRR should desirably possess the following qualitative characteristics (Ibrahim, 2003).

1) The report should contain a statement of its objectives, which helps in assessing the basis of data collection and the reason for adopting the particular form of presentation.

2) The objective of such a report should be to discharge accountability towards society.

3) Information provided should be directly related to the user's need.

4) Information should not be manipulated and be presented in a manner understandable to non-technical people.

A growing number of organizations world-wide are choosing to use their annual reports as a vehicle to carry social responsibility accounting. The annual report is an ideal vehicle for achieving environmental kudos because the publication of the organization's environmental policy is a crucial step maximizing the effect of the organization's corporate image.

Since most of the SRA information is non-financial in nature, this information is usually found in the Annual Report disclosure section, instead of being part of the major financial report. Usually it is found in the section of in the chairman's statement, cover page or back page, Managing Director's report, highlights of the year and sometimes even in the mission and vision statement of the organization. Some organizations also use photographs, charts and graphical presentation to illustrate the social activities, such as community projects, that have been undertaken by the firm during an accounting period.

With the increase in social pressure on firms for corporate social responsibility from the 1960's, social disclosure has become gradually popular through out the world. Processes for development of this reporting imperative are in progress all over the world. However, no concrete shape or clear methodology has been identified. 


\subsection{Forms, Content and Techniques of Social Responsibility Reporting}

Due to lack of legislation on forms, content and techniques of social responsibility reporting, there are no standard for forms, content and reporting techniques.

\subsubsection{Form of Reporting}

According to the Association of Certified Chartered Accountants (ACCA) of Malaysia (2002) all reporting companies used their published annual report in communicating environmental information to their stakeholders. There was a general increase in terms of the number of pages companies allocated in their annual reports for communicating environmental information. As at 1999 , more than $95 \%$ of thee reporting companies limited to a page within the annual report information on environmental activities. By 2001, 40\% were devoting more pages of information.

\subsubsection{Concept of Reporting}

Reporting companies that have greater interaction with the environment or resource-based companies (such as plantation, forestry, power generation, oil and gas extraction, and wave treatment and supply) tend to focus on environment issues. Manufacturing-based industries were more likely to combine environmental with Occupational Safety and Health (OSH) issues, while the construction sectors tended to focus only on OSH issues (Ibrahim, 2003).

Few companies have started to include environmental performance data as an indication of their environmental impacts show their yearly progress and include their environmental objectives and targets. Environmental Management and achievements were the two areas most commonly focused by reporting companies. A few companies include information on organizational context, commitments and their stakeholder's engagement. Very few companies reported environmental financial information or acknowledgement of negative information.

\subsubsection{Reporting Techniques of Social Activities}

Some of the approaches for reporting social activities include:

I. Narrative disclosure in foot notes to financial statement showing information concerning environmental issues and effort.

II. Non-monetary information on pollution control facilities and emission.

III. A sophisticated social audit report with sections dealing with the company and the shareholders, the employees, the clients, the general public and the community.

IV. A comprehensive report providing all the social benefits and the social costs resulting from the firm's activities.

V. A comprehensive social cost benefit model that matches the direct benefits and the direct cost generated by an organization showing the resulting net surplus or deficit to the society (Ibrahim, 2003).

\subsection{Arguments for and against Social Responsibility Accounting}

The issue of organizations being socially responsible had been highly contested. The arguments have produced two schools of thoughts; one supporting the view that organizations should have social responsibility and the other opposing it.

Keith (2000) opined that in addition to an organization carrying out its normal and legitimate operations leading to producing goods and services efficiently, it must also engage in some other activities which make it socially responsible. He argued that corporations are creatures of society and should respond to societal demands, the long run interests of organization are best served when organizations assume social responsibilities.

The opposing side includes Milton (1981) and Roberts (1992); Donaldson (1982) and a host of others. This group is of the opinion that the main objective of organization is to provide goods and services effectively and to make as much profit as possible for its owners; an organization is an economic institution whose legal function is economic performance, not social activities. They argued further that a socially responsible activity weakens the firm's goal of profit maximization. Each time the firm's money is spent on social activities like community renewal, hiring and training the minorities and hard-core unemployed, granting scholarships, profit opportunities are missed. Money spent on such programmes could better be spent in more aggressive advertisement and selling or in production efficiency, which will definitely increase profit potentials.

2.8.1 Arguments for Social Responsibility

i. It enhances the image of the company 
The increasing pressure on companies to be responsible to the society has influenced them to operate business in environmentally and socially responsible manner. Companies are to be responsible not just to the shareholders but also all the other stakeholders including the community. Therefore, companies' profit maximization goal has to be balanced with social goals. Managers need to be convinced that social responsibility and profit maximization need not to be conflicting goals. Instead, as many multi-nations in the developed countries have learnt, social responsibility can be used as a strategic tool to enhance the reputation and public image of a company, while at the same time, prove to be profitable for the company (Ahmad \& Abdul, 2002). An enhanced public image would help them gain more customers, better employees and other benefits. Furthermore, a favourable corporate image is also crucial from the investor's point of view, as investors are usually eager to buy stocks of organizations that support socially responsible activities. Firms win greater public confidence by showing commitment to sustained community development.

ii. A mature and stable outlook

The social responsibility account disclosure will result in the publication of diverse and varied points of view or environmental issues. This will help give the organization a mature and stable outlook. Social responsibility accountability moreover has emerged in significance due to the general rise in the interest and concern about the environment, employee welfare, health and safety among the users of the financial information. This demand has led to greater accountability on the social impact of businesses. Studies have shown that shareholders make better decisions if more information is made available to them and the more efficient the market tend to be (Epstein \& Freedman, 1994).

iii. Firm's ability to develop solutions for economic and social problems

Measuring changes in environmental impact at the level of the individual product is an essential element on the way to a more sustainable business. The satisfaction of human needs in the most efficient way is essential. It is also essential to build both shareholders value and corporate social responsibility. This enables company to show its ability to incorporate its responsibility into society and develop solutions for economic and social problems(Epstein \& Freedman, 1994).

\section{iv. Positive Financial Implication}

By devoting organizational resources to social concern, it would subsequently lead to other improvements as stimulated by the multiplier effect. For example, pollution control measures undertaken by the business organization may lead to the improvement in the appearance and general climate of the city(Ahmad \& Abdul, 2002).

\section{v. Changed Public Expectation of Business}

Public needs have changed and this has led to new expectations. Society has a charter with business for the latter to exist, and this charter can be amended or revoked at any time that business fails to live up to the society's expectation and needs(Ahmad \& Abdul, 2002).

\section{vi. Better Environment for Business}

The creation of better social environment benefits both society and business. The society gains through the better neighbourhood and employment opportunities. A cleaner and safer neighborhood on the other hand means a more stable community in which to operate (Ahmad \& Abdul, 2002).

Fewer unemployed persons reduce the chances of social vices and provide the additional income to purchase the firm's product or services. Better educated members of the community provide a more attractive labour pool from which to draw personnel (Ahmad \& Abdul, 2002).

\subsubsection{Arguments against Social Responsibility}

\section{i. Profit Maximization}

The primary aim of business is to maximize profit by concentrating strictly on economic activities, and as long as it stays within the rules of the game. Social concerns could reduce economic efficiency.

\section{ii. Cost for Social Responsibility}

Eventually, society must pay for social responsibility by business through either high prices or in the firm's product mix providing less consumer satisfaction. Social involvement will create excessive costs for business, and the citizens of the society will ultimately pay for these costs.

iii. Business has Enough Power 
Business has enough economic power and when it takes an additional non-economic power, it will increase its overall power and influence. This may lead to a society dominated by the business community. If this happens, the society as whole stands to lose.

iv. Difficulty in measuring social responsibility

Social actions are often difficult to measure. There is always the problem of comparing potential benefits with potential cost of social action by business (Ahmad \& Abdul, 2002).

\section{Methodology}

An attempt was made in this study to establish the extent to which social responsibility cost influences profitability. The research design adopted for the study is the exploratory design. This is because it sought to explain social responsibility cost and its influence on banks profitability. The population of this study comprises all the commercial banks in Nigeria. Hence, the population size is twenty-one (21) commercial banks. In view of the researcher's inability to reach out to the entire population, and in order to gain the advantages of an in-depth study and effective coverage, samples were drawn using simple random sampling from the 21 commercial banks in Nigeria. Five of these commercial banks (First Bank of Nigeria Plc, Guaranty Trust Bank Plc, United Bank of Africa Plc, Zenith Bank Plc and Eco Bank Plc) were randomly selected from the study population of 21. According to Balsely and Clover (1988), it is common in research studies to use 10 percent sample size, because sample size of 10 percent of the universe has been proved to be more than adequate in research projects. Ogolo (1996) corroborates this when he posits that where a population is known, at least 10 percent of it constitutes a researchable sample. For this study five (5) commercial banks where selected, amounting to $23.81 \%$ of the universe.

A need to have a better understanding of this study leads us to the consultation of a number of related materials. Most of the required data of this work were obtained from published articles, journals, internet materials and annual reports. Thus, this study relied heavily on secondary data.

The economic model used in the study (which is in line with what is mostly found in the literature) is given as:

$$
\mathrm{Y}=\beta_{0}+\beta_{1} \mathrm{~F}_{\mathrm{it}}+\beta_{2} \mathrm{~F}_{\mathrm{it}}+\mathrm{e}_{\mathrm{it}}
$$

Where, $Y$ is the dependent variable, $\beta_{0}$ is a constant, $\beta_{1}$ is the coefficient of the explanatory variable, $F_{\text {it }}$ is the explanatory variable, and $\mathrm{e}_{\mathrm{it}}$ the stochastic error term.

By adopting the economic model as in equation (1) above specifically to this study, the regression model used is based on Eyre (1982) stakeholder theory.

$$
\mathrm{PROF}=\beta_{0}+\beta_{1} \mathrm{SC}+\beta_{2} \mathrm{PC}+\mathrm{e}_{\mathbf{i t}}
$$

Where:

$\begin{array}{ll}\text { PROF } & =\text { Profitability } \\ \text { SC } & =\text { Social Cost } \\ \text { PC } & =\text { Pollution Cost } \\ \beta_{0} & =\text { a constant, } \\ \beta_{1} \text { and } \beta_{2} & =\text { the coefficient of the explanatory variable, } \\ \mathrm{e}_{i t} & =\text { the stochastic error term. }\end{array}$

\section{Data Analysis}

$<$ Insert Table 1 here>

Table 1 shows the summary of the regression results of social responsibility cost (social cost and pollution cost) and profitability. From the result, it could be found that all the independent variable is significant when compared with the table value at 5\% level. Specifically, a $1 \%$ increase in the independent variables would lead to a decrease in profitability in the short run.

The explanatory power of the model as informed by the adjusted R-square is 0.960 or $96 \%$, and is statistically significant given the high value of the F-statistic (i.e. 55.873).

The model demonstrates a good fit given that about $96 \%$ of the variations in the dependent variable profitability is jointly explained by changes in the observed behaviour of the independent variable. The relatively high adjusted R-square of $0.96(96 \%)$, shows that the model fits the data well. About $4 \%$ variations in profitability can be explained by other unknown variables not captured in the present model. The high significant F-statistic value $\left(\mathrm{df}_{\mathbf{1}}=1\right.$ 
and $\mathrm{df}_{2}=3$ ) of 55.873 (p-value .000) confirms that the high adjusted R-square did not arise by chance [N/B: F0.05 $\left(\mathrm{df}_{1}=1\right.$ and $\left.\left.\mathrm{df}_{2}=3\right)=10.13\right]$. Therefore, the model is robust.

The test for autocorrelation, the calculated Durbin Watson $(\mathrm{D} / \mathrm{W})$ is 2.065 . From the table $\mathrm{D} / \mathrm{W}$ reading, one makes use of the following information: $\mathrm{K}=2$ variables, $\mathrm{n}=5$ and at $5 \%$ level: $\mathrm{du}=1.001,4-\mathrm{du}=2.229, \mathrm{dI}=1.335$ and 4- $\mathrm{dI}=2.965$. By inspection, the $\mathrm{D} / \mathrm{W}$ value of 2.065 falls within the $\mathrm{dI}$ and 4-du region (i.e. 1.335 and 2.229 in this case), therefore our calculated $\mathrm{D} / \mathrm{W}$ falls within the region of no autocorrelation.

\subsection{Discussion of Findings}

Based on the analysis and empirical results the study revealed that the coefficient of Social Cost (SC) is negative, meaning that there exist a negative influence between social cost and profitability in the short run. This agrees with the findings of Eyre (1982).

The study also revealed that pollution cost does have a significant influence on profitability. This finding is highly supported by the finding arrived at by Adams (2000) who in his study found out that a significant influence exist between pollution abatement cost and corporate profitability and dividend paid to shareholders. According to him, most organizations have been compelled to effectively treat their waste before disposal so as to reduce the rate of pollution caused by the company. Equally, most organizations are required to build a high chimney into the air to ensure that smoke from the company is sent off high in the air. All these costs help increase the expenses incurred by the firm thereby reducing profitability. This finding is also in agreement with the finding of Obajimi (2007) who found out that recent environmental threats such as raising of sea level, global warming and protection of ozone layer have forced several companies to engage in new strategies to reduce the amount of pollution caused by their companies. These new strategies have involved the organizations to incur costs higher than the cost they used to incur on pollution before reducing the profit level of the organization.

\section{Conclusion and Recommendations}

From the findings, it could be concluded that social responsibility cost is as vital as all other liabilities of the banks, and it requires proper management. When the needs or rights of relevant stakeholders are met or guaranteed, a conducive environment is created for increased profitability of an organization. Where commercial banks neglect their responsibility to the other stakeholders in the environment, the result is invariably a strained relationship between them. The implication of this is that the operation of the banks would be adversely affected. Generally, because there is no standard social responsibility accounting guidelines, Nigerian commercial banks do not show in their published annual account details of their financial commitment to the environment. This is a disservice to the users of the published annual report because such reports lack the critical information about important environmental expenditure.

Based on the findings it is recommended that:

1) Nigerian commercial banks should ensure that expenditure on social responsibility cost reflect responsive social responsibility policy as dictated by international best-practice. Such a policy should be implemented effectively by the banks in order to meet stakeholders' expectations.

2) The Financial Reporting Council (FRC) of Nigeria should collaborate with other professional bodies, the academia and other stakeholders to produce a standard on social responsibility accounting and should ensure there is compliance and transparency in the process.

3) To add credibility to social responsibilities accounting disclosures, some form of audit may become necessary in the near future to improve the effectiveness of the contemporary social responsibilities disclosures. This social audit would attempt to systematically review and report on the accountability of these disclosures and even make recommendations on areas for improvement. Commercial banks should be encouraged to include an independent verification by the auditors who state that they are satisfied with the information presented in the annual report, which includes the banks' effort on community involvement.

\section{References}

Aboribo, R. I. (2001). The political economy of environmental pollution in the Niger Delta: From compensation to participation. African Journal of Environmental Studies, 2(1), 183-188.

Abul, K. J. (1998). Social choice and individual values. Yale, Yale University Press.

Ahmad, N., \& Abdul, R. (2002). Awareness of the Concept of corporate Social responsibility among Malaysian Managers in selected public listed companies. 
AI-Hayali, W. U. (1998). Accounting Measurement procedures of environment pollution. Journal of industrial cooperation in the Gulf, 3(5), 71-72.

Al- Hamadeen, R. (2002). Social responsibility accounting in Jordan hotel institutions, a field study, unpublished Mathesis. AI AI beit University Mafraz, Jordan.

Arntzen, J. (1997). Sustainable development and environmental assessment, Splash, 13(1), 10-13.

Awasthi, A. K. (2009). Environmental issues in audit. [Online] Available: http://www.aud.ecosy.com/environmentalaccountingissues/ concept/OBII5673 (October 3, 2009)

Balsely, H. C., \& Clover, V. T. (1988). Research for business decisions: Business research method (4th ed.). Ohio: Horizons Publishers.

Buskirk, R. H., Green, D. J., \& Rodges, W. C. (1976). Concept of business. New York: Oak Tree Press.

Campbell, D. J. (2000). Legitimacy theory or managerial reality construction? Corporate social disclosure in marks and spender Plc Reports (1990-1997). Accounting Forum, 2, 80-101.

Cohen, A. R., Fink, S. L., Gadon, H., \& Willits, R. D. (2001). Effective behaviour in organizations: Cases, concepts, and student experience ( $7^{\text {th }}$ ed.). New York: McGraw- Hill.

Donaldson, T. (1982). Corporations and Morality. Prenticehall, Englewood Cliffs, London.

Epstein, M. J., \& Freedman, M. (1994). Social disclosure and the individual investor. Accounting, Auditing \& Accountability Journal, 7(4), 94-109.

Eyre, E. C. (1982). Mastering basic management. Hong Kong: Macmillan Press.

Friedman, H. J. (1980). Does business have social responsibility? New York: Harper and Row.

Gamble, G., \& Jackson, H. (1996). Environmental Disclosure annual report. An internal Journal of Accounting, 31(3), 293-331.

Gilpin, A. (1995). Environmental impact assessment. Cambridge: Cambridge University Press.

Gray, R. H. (1988). Corporate Social Environmental Reporting: A review of the Literature and a longitudinal study of UK Disclosure. Accounting, Auditing \& Accountability Journal, 8(2), 47-77.

Gray, R. H. (2001). Current developments and trends in social and environmental auditing: Reporting and attestation. International Journal of Auditing, 4(3), 247-268.

Gray, R. H. (2002). The accounting profession and the environmental crisis (or can accountancy save the world) International Journal of Auditing, 3, 250-265.

Gray, R. H., Javad, M., \& Porter, D. M. (2001). Social and Environmental Disclosure and Corporate Characteristics: A Research Note and Extension. Journal of Business Finance and Accounting, 28(3), 327-356.

Gray, R. H., Neimark, D. L., \& Lehman, K. (1995). Corporate Social reporting Emerging trend in accountability and the social contract. Accounting. Auditing and Accountability Journal, 1(1), 25-26.

Growther, D. (2000). Social and environmental accounting. London: Financial Times Prentice Hall.

Guthrine, J., \& Parker, L.D. (1989). Corporate Social Reporting: A rebuttal of Legitimacy theory. Accounting and Business Research, 9(76), 343-352.

Ibrahim, B. W. (2003). An alternative approach to efficient pollution control in Nigeria. Ilorin: Rasjet publishers.

International Union for Conservation of Nature. (1980). Environmental accounting: What is it all about? Washington D. C.: The World Conservation Union.

Jebreel, N. (1999). Responsibility Accounting in Jordanian Industrial public joint stock companies field study. Unpublished Mathesis, Faculty of Economics \& Administrative sciences, AI AI Beit University, Mayraz, Jordan.

Keith, G. C. (2000). Impact of environmental regulations on the U.S. steel industries. Pittsburg: Carnegic Mellow University.

Milne, M. J. (2002). Positive Accounting Theory, Political costs and social Disclosure Analysis: A Critical look". Critical perspectives on Accounting, 13, 369-395.

Milton, F. (1981). Free to Choose. Avon, New York.

Obajimi, E. D. (2007). Air pollution - A threat to healthy living in Nigerian rural towns. Ibadan: Evans Brother. 
Ogolo, M. B. (1996). Student guide to writing research and project proposals. Port Harcourt: City Circle Press.

Ozumba, C. I. (1999). Striking a balance between oil exploration + protecting the environment: The SPDC experience. NAPE Bulletin, 14(2), 120-125.

Repetto, R. (1989). Economic incentives for sustainable production. In G. Schramm \& J. Worfood (Eds.), Environmental management and economic development. Baltimore: The John Hopkins University Press.

Rilwani, M. L. (2001). Environmental impact assessment and Nigerian development: A spatial perspective. Africa Journal of Environmental Studies, 2(2), 141-145.

Roberts, R. (1992). Determinant of Corporate Social Responsibility disclosures. Accounting, Organizations and Society 17(6), 595-642.

Salamis, A. T. (2000). Local communities and sustainable development: A case study of forestry management in rural south-western Nigeria. African Journal of Environmental Studies, 2(12), 18-24.

Shacer, A. (1988). Possibility of Expression the Environment Performance of Economic Enterprises through the Conceptual Framework of the accounting theory. Scientific journal, faculty of economic, Asiout University.

Smith, L. M. (2003). Accounting guidelines for environmental issues. New York: Oak Tree Press.

Tinker, T. Neimark, M., \& Lehman, C. (1991). Falling down the Hole in the middle of the Road; political quickesm in corporate Social Responsibility. Accounting, Auditing \& Accountability Journal, 4, 28-54.

Twaijn, (1988). Social Responsibility Indicators in the Jordaman Joint stock companies. Dirasat, University of Jordan.

Wilmhurst, T., \& Frost, G. (2000). Corporate Social Environmental reporting: A test of Legitimacy theory. Accounting, auditing and accountability Journal, 4, 10-26.

World Conference on Environmental Development. (1987). Our common future (the Brandtland report). Oxford: Oxford University Press.

Yomere, G. O. (2000). Corporate social responsibility of the oil company in the Niger Delta area. Paper presented at the national conference on management of petroleum and energy resources held in Abuja on $21^{\text {st }}-25^{\text {th }}$ August.

Table 1. Regression results on social responsibility and performance

\begin{tabular}{|c|c|c|c|c|}
\hline Variable & $\begin{array}{l}\text { Estimated } \\
\text { Coefficient }\end{array}$ & $\begin{array}{c}\text { Standard } \\
\text { Error }\end{array}$ & T-Statistic & P-Value \\
\hline $\mathrm{C}$ & 4705.630 & 6004.425 & 3.855 & .000 \\
\hline SRC & -5.914 & 26.849 & 2.725 & .000 \\
\hline $\mathrm{PC}$ & -3.225 & 15.124 & 4.005 & .000 \\
\hline \multicolumn{3}{|c|}{$\mathrm{R}^{2}$} & \multicolumn{2}{|l|}{$=.980$} \\
\hline \multicolumn{3}{|c|}{$\mathrm{R}^{2}(\mathrm{adj})$} & \multicolumn{2}{|l|}{$=.960$} \\
\hline & \multicolumn{2}{|c|}{ F-Statistic $\left(\mathrm{df}_{1}=1, \mathrm{df}_{2}=3\right)$} & \multicolumn{2}{|c|}{$=55.873$} \\
\hline & \multicolumn{2}{|c|}{ Durbin Watson Statistics } & \multicolumn{2}{|l|}{$=2.065$} \\
\hline & \multicolumn{2}{|l|}{ SER } & \multicolumn{2}{|c|}{$=52.230$} \\
\hline & \multicolumn{2}{|l|}{$\mathrm{N}$} & \multicolumn{2}{|c|}{$=5$} \\
\hline & \multicolumn{2}{|c|}{ Dependent Variable: PROF } & & \\
\hline
\end{tabular}

Source: Researcher's estimation, 2012 